\title{
Group Guidance Based on Local Strength to Improve the Competence of Counselors
}

\author{
Denok Setiawati ${ }^{1, *}$ Hadi W. Wiryosutomo ${ }^{1}$ Najlatun Naqiyah ${ }^{1}$ \\ ${ }^{1}$ Universitas Negeri Surabaya \\ *Corresponding author. Emai l: denoksetiawati@unesa.ac.id
}

\begin{abstract}
The measurement of counselor competency improvement through group guidance training is the aim of this study. Types of qualitative research with data collection techniques are interviews, open questionnaires, and literature studies. The research sample was 67 school counselors who were obtained using a purposive non-random sampling technique. The data analysis technique used is triangulation. The results showed usefulness and an increase in academic and professional competence in providing group guidance services based on local strengths by $97.68 \%$. Forms of local strength in games, ludruk, parikan jula juli, and traditional games can be included in selecting topics, interlude activities, and service techniques. This research can also contribute to the innovation of group guidance services, especially in helping to facilitate the development of students towards independence.
\end{abstract}

Keywords: Competency of school counselors, Group guidance, Local strength.

\section{INTRODUCTION}

The complete figure of the counselor's competence consists of academic competence and professional competence. Academic competence emphasizes two abilities: mastering the theoretical repertoire of guidance and counseling and understanding the counselee to be served. Increasing the competence of counselors is not easy because it is constrained by problems in the field, especially during the Covid-19 pandemic. On the other hand, as part of the three obligations of higher education, the academic community must be sensitive to problems in society and do community service. The community referred to in this case is school counselors and junior high school students.

One of the services that cannot run well is the group guidance service, even though the service has extraordinary benefits. The description of group guidance services is important to support development, especially career development, social development, and increasing self-awareness [1].

The purpose and function of group guidance services are so that each member can speak in front of many people; able to express opinions, ideas, suggestions, responses, feelings to many people; learn to respect the opinions of others; is responsible for the opinions expressed; able to control oneself and restrain emotions (negative psychological turmoil); can tolerate; become familiar with each other, and discuss common problems or topics that are felt or are of common interest [2]. In addition, even if group guidance services can be implemented, the implementation is still standard and requires innovations, one of which is through group guidance services by utilizing local strengths.

The needs assessment results of 138 students in Surabaya, six school counselors in Surabaya need group guidance services by utilizing local strengths in delivering messages. The service is carried out by providing concrete actions in the form of soft skill development in the form of the ability to provide group guidance services by utilizing local strengths, namely by utilizing the media of Jula-Juli Suroboyoan and Parikan. Regarding Jula-Juli, the team was not trained. However, the team only used media that came from existing YouTube. The focus of this research is to reveal the benefits of local strength-based group guidance training for junior high school counselors, identify the presence or absence of new knowledge, attitudes and skills after training, and analyze the placement of local strengths in group guidance. 


\section{METHODS}

This type of research is qualitative research. Qualitative research is used to examine the condition of natural objects, where the researcher is the key instrument. Data collection techniques used are interviews, questionnaires, and literature studies. The interview consisted of three main questions: the usefulness of the training, new knowledge, attitudes, and skills acquired, and how to incorporate local strengths in group guidance. While the open questionnaire contains seven items of questions, including the types of local strengths selected, the application of local strengths, the stages of group guidance carried out, new things that can be obtained after training, the benefits of training, and suggestions for further training.

For literature studies, there are two sources that are used as references, [2] and [3]. This book is used to reveal the nature of group guidance in terms of understanding, objectives, benefits, stages of group guidance. This article explores the effectiveness of local wisdom-based guidance and counseling and the types of local wisdom applied in guidance and counseling.

The sample of this study was 67 counselors for junior high schools in Surabaya, which were taken using a purposive non-random sampling technique. In comparison, the data analysis technique uses data triangulation. Triangulation is the most commonly used method for increasing data validity in qualitative research.

There are four kinds of triangulation techniques, namely (1) data/source triangulation, (2) investigator triangulation, (3) methodological triangulation, and (4) theoretical triangulation. This triangulation is a technique based on a phenomenological mindset that is multi-perspective. This means that to draw solid conclusions, it is necessary not only from one point of view. In this study, data were obtained from unstructured interviews, open questionnaires, and literature studies. The data sources are junior high school students in Surabaya, school counselors, and sociology lecturers. Data analysis was carried out with the following steps: (a) Data reduction, (b) Data display or data presentation (c) Data Verification (Withdrawal of Conclusions).

\section{RESULTS AND DISCUSSION}

This training uses an experiential learning model. This intervention strategy consists of four stages, namely: concrete experience, reflection, conceptualization/abstract thinking, and application [4]. A brief explanation is as follows:

\section{a. Real Experience Stage}

The real experience stage is carried out by inviting trainees to carry out group guidance as they usually do.

\section{b. Reflective/Reflective Observation Stage}

The stages of reflection observation are obtained through observation activities carried out by research subjects on the group guidance they do and its implications for achieving service goals.

\section{c. Conceptualization Stage}

The conceptualization stage is to understand group guidance with steps that combine local strengths in group guidance. The stages of group guidance consist of 4 stages, namely the formation stage, the transition stage, the activity stage, and the termination stage.

\section{d. Implementation Stage}

The active experimentation stage provides school counselors with opportunities to apply the material obtained in training in real situations. Participants are given the task of recording the situation they experienced previously with the formats that will be provided.

Several studies show the success of experiential learning. Although experiential learning has weaknesses, this approach also has advantages [5]. Examples of research on the effectiveness of experiential learning in improving academic performance, cognitive skills, and social skills are LealRodriguez, Antonio L., and Albort-Morant [6], and Voukelatou [7]. The above strategy is applied to train the ability of school counselors ability to provide local strength-based group guidance services.

The results of interviews with school counselors about the usefulness of training as much as $97.68 \%$ are that school counselors feel the benefits of training new knowledge, attitudes, and skills and incorporating local strengths in group guidance. The results of the questionnaire to school counselors obtained data as listed in table 1.

The results of the interview above show that counselors feel the benefits of group guidance training, have increased academic competence in mastering the theoretical repertoire of local strength-based group guidance, and have increased professional competence in terms of practicing group guidance by incorporating local elements through training. 
Table 1. Questionnaire results from school counselors

\begin{tabular}{|c|c|}
\hline Questions & Answer \\
\hline $\begin{array}{l}\text { Preferred local } \\
\text { strength: }\end{array}$ & $\begin{array}{l}\text { Jula-Juli Suroboyo, Parikan, } \\
\text { Traditional Games, ludruk }\end{array}$ \\
\hline Applied to & $\begin{array}{l}\text { 1. Selection of Topics with Local } \\
\text { Strength } \\
\text { 2. Introduction using local } \\
\text { power } \\
\text { 3. Interlude/Icebreaking } \\
\text { 4. Traditional Game Techniques }\end{array}$ \\
\hline $\begin{array}{l}\text { Stages of group } \\
\text { guidance carried } \\
\text { out by School } \\
\text { Counselors. }\end{array}$ & $\begin{array}{l}\text { Forming stage } \\
\text { Transition Stage } \\
\text { Activity step } \\
\text { Termination Stage }\end{array}$ \\
\hline $\begin{array}{l}\text { New things that } \\
\text { School Counselors } \\
\text { get with this } \\
\text { training }\end{array}$ & $\begin{array}{l}\text { group guidance training } \\
\text { Collaborative group guidance } \\
\text { by incorporating local strengths }\end{array}$ \\
\hline $\begin{array}{l}\text { Was this training } \\
\text { useful for you? }\end{array}$ & $\begin{array}{l}\text { Very useful } 90.7 \% \\
\text { Helpful } 6.98 \% \\
\text { Not responding } 2.32\end{array}$ \\
\hline $\begin{array}{l}\text { Does the speaker } \\
\text { master the material } \\
\text { being trained? }\end{array}$ & $\begin{array}{l}\text { Very dominant } 88.37 \% \\
\text { Enough to master } 6.98 \% \\
\text { Mastering } 2.32 \% \\
\text { Not responding } 2.32 \%\end{array}$ \\
\hline $\begin{array}{l}\text { Your suggestions } \\
\text { for further training }\end{array}$ & $\begin{array}{l}\text { Can display direct examples and } \\
\text { practice directly, } \\
\text { Performed regular }\end{array}$ \\
\hline
\end{tabular}

The way to include local strengths in group guidance is by choosing topics that contain local strengths, at the time of introduction using local strengths, through interlude activities, and during the application of traditional game techniques - the result of literature studies presented in Table 2 .

Based on the literature review in Table 2, the types of guidance and counseling services that can be applied to facilitate student development include types of services that fall into pattern 17 or can also use a comprehensive guidance and counseling approach. This study can be used as a guide to improving academic competence in understanding the theoretical repertoire of guidance and counseling, especially the types of services that can be applied to facilitate student development.
Table 2. Results of literature study

\begin{tabular}{|c|c|c|}
\hline & Literature 1 & Literature 2 \\
\hline Title & $\begin{array}{l}\text { Dasar-dasar } \\
\text { Bimbingan dan } \\
\text { Konseling }\end{array}$ & $\begin{array}{l}\text { Peace Guidance } \\
\text { and Counseling } \\
\text { Based on } \\
\text { Indonesian Local } \\
\text { Wisdom }\end{array}$ \\
\hline Year & 2004 & 2019 \\
\hline $\begin{array}{l}\text { Various } \\
\text { guidance and } \\
\text { counseling } \\
\text { services }\end{array}$ & $\begin{array}{l}\text { There are } \\
\text { various types of } \\
\text { services, both } \\
\text { basic and } \\
\text { supporting } \\
\text { services, namely } \\
\text { "pola 17.' }\end{array}$ & $\begin{array}{l}\text { There are various } \\
\text { types of services, } \\
\text { namely } \\
\text { comprehensive } \\
\text { guidance and } \\
\text { counseling. }\end{array}$ \\
\hline $\begin{array}{l}\text { Contribution } \\
\text { to this } \\
\text { research }\end{array}$ & $\begin{array}{l}\text { Focus on the } \\
\text { nature of } \\
\text { guidance and } \\
\text { counseling, } \\
\text { understanding, } \\
\text { objectives, } \\
\text { functions, } \\
\text { history, } \\
\text { principles, and } \\
\text { matters relating } \\
\text { to the basic } \\
\text { concepts of } \\
\text { guidance and } \\
\text { counseling } \\
\text { Guidelines for } \\
\text { improving } \\
\text { academic } \\
\text { competence, } \\
\text { especially in } \\
\text { terms of the } \\
\text { benefits and } \\
\text { objectives of } \\
\text { guidance and } \\
\text { counseling in } \\
\text { facilitating the } \\
\text { development of } \\
\text { students }\end{array}$ & $\begin{array}{l}\text { Focus on } \\
\text { guidance and } \\
\text { counseling } \\
\text { approach based } \\
\text { on local wisdom } \\
\text { to overcome } \\
\text { aggression } \\
\text { behavior } \\
\\
\text { Guidelines for } \\
\text { improving } \\
\text { academic } \\
\text { competence, } \\
\text { especially in } \\
\text { terms of } \\
\text { the types of } \\
\text { services that can } \\
\text { be applied in } \\
\text { guidance and } \\
\text { counseling } \\
\text { services based } \\
\text { on local wisdom } \\
\text { in overcoming } \\
\text { student } \\
\text { problems }\end{array}$ \\
\hline
\end{tabular}


Several studies show that training can increase the competence of counselors through reality counseling training [8] [9]. In addition, group guidance training has also been proven to improve academic competence and professional competence, as research on the effectiveness of group guidance in improving the competence of prospective counselors [10] and the effectiveness of group guidance in building religious character and other studies [12].

\section{CONCLUSION}

The results showed an increase in academic competence and professional competence in group guidance services by incorporating local elements through training. The way to include local strengths in group guidance is by choosing topics that contain local strengths, at the time of introduction using local strengths, through interlude activities, and during the application of traditional game techniques. This study also revealed that there were innovations in providing group guidance services. The weakness of this study was the treatment design and the generality of the local strengths being trained. For this reason, further research can be applied to experimental type research with a specialization on the type of local strength that is applied.

\section{REFERENCES}

[1] R.L Gibson and M.H. Mitchell, Bimbingan dan Konseling., Yogyakarta: Pustaka Pelajar, 2010.

[2] P. Prayitno, and A. Erman, Dasar-dasar Bimbingan dan Konseling, Jakarta: Rineka Cipta, 2004.

[3] A. Supriyanto and W. N. E. Saputra, "Peace Guidance: Training For School Counsellors At Preventing Tendention To Aggression For Students," PROFICIO, vol. 2, no. 2, 35-43, 2021.

[4] D. A. Kolb, Experiential learning: Experience as the source of learning and development, FT Press, 2014.

[5] J. Roberts,. "From the editor: The possibilities and limitations of experiential learning research in higher education." , pp 3-7, 2018.

[6] Leal-Rodriguez, L. Antonio, and G. AlbortMorant, "Promoting innovative experiential learning practices to improve academic performance: Empirical evidence from a Spanish Business School," Journal of Innovation \& Knowledge, vol. 4, no. 2, 97-103, 2019.

[7] G. Voukelatou, "The contribution of experiential learning to the development of cognitive and social skills in secondary education: A case study." Education Sciences, vol. 9, no. 2, pp 127, 2019.

[8] D. Putranti and N. E. Safitri, "Peningkatan Kompetensi Guru BK/Konselor dalam Pelaksanaan Layanan Bimbingan Karir di Sekolah Menengah Kejuruan (SMK)." In Seminar Nasional Pendidikan, pp. 40-46, 2017.

[9] E. Munawaroh, C. T. Anni, and Sunawan, "Meningkatkan Kompetensi Profesional Konselor melalui Pelatihan Konseling Realita." Jurnal Abdimas , vol. 23, no. 1, pp.42-47, 2019.

[10] F. Aryani and Muhammad Ilham Bakhtiar, "The Development of group guidance service model to increase the competence of counselor candidate." GUIDENA: Jurnal Ilmu Pendidikan, Psikologi, Bimbingan dan Konseling, vol. 7, no. 1, pp. 121129, 2017.

[11]A. Supriyanto, W.N.E Saputra., B. Astuti, Peace Guidance and Counseling Based on Indonesian Local Wisdom. Atlantis, 2019.

[12] H.C. Mamahit, "Cinema education method, is it work for group guidance and counseling?," Journal of Counseling and Educational Technology, vol. 3, no. 2, pp. 68-73, 2020. 